\title{
The cardiopulmonary effects of sevoflurane, isoflurane and halothane anesthesia during spontaneous or controlled ventilation in dogs"
}

\author{
Göksen ÇEÇEN ${ }^{1}$, Ayşe TOPAL ${ }^{1}$, O. Sacit GORGÜL ${ }^{1}$, Semra AKGÖZZ \\ ${ }^{1}$ Department of Surgery, Faculty of Veterinary Medicine, University of Uludag, Bursa; ${ }^{2}$ Department of Biostatistics, Faculty of \\ Medicine, University of Canakkale Onsekiz Mart, Canakkale - Turkey.
}

\begin{abstract}
Summary: The objective of this study was to investigate the cardiopulmonary effects of sevoflurane (SEV), isoflurane (ISO) and halothane (HAL) anesthesia during spontaneous ventilation (SV) or controlled ventilation (CV) in dogs. An experimental study was designed. Sixty healthy cross breed dogs were used for the study. Dogs were randomly allocated to six anesthesia groups ( $n=10$ in each group): SEV/SV; SEV/CV; ISO/SV; ISO/CV; HAL/SV; HAL/CV. After premedication with xylazine $\mathrm{HCl}$, anesthesia was induced with thiopental sodium. Inhalation anesthesia was maintained for 90 minutes with SEV, ISO, or HAL. Cardiopulmonary parameters [heart rate (HR), respiratory rate (RR), mean arterial blood pressure (MAP), end tidal carbon dioxide level $\left(\mathrm{ETCO}_{2}\right)$, oxygen saturation $\left(\mathrm{SpO}_{2}\right)$, central venous pressure $(\mathrm{CVP})$, body temperature, arterial partial pressure of oxygen $\left(\mathrm{PaO}_{2}\right)$, arterial partial pressure of carbon dioxide $\left(\mathrm{PaCO}_{2}\right)$, and arterial $\mathrm{pH}$ ] were measured after induction of anesthesia; the first measurement was taken one minute after the loss of consciousness with SEV, ISO, or HAL and the others were done at 15th, 30th, 45th, 60th and 90th minutes. There was not any significant difference in HR between anesthetics among SV and CV. RR decreased significantly during ISO and HAL anesthesia in SV $(\mathrm{p}<0.001)$. MAP decreased significantly in all groups but there was not any significant difference between the ventilation modes. There was a significant decrease in $\mathrm{ETCO}_{2}$ during $\mathrm{CV}$ compared to $\mathrm{SV}$ ( $\mathrm{p}<0.001$ ). The $\mathrm{CVP}$ values during anesthesia with SEV in SV were lower than those of other anesthetics $(p<0.001)$. Body temperature decreased significantly during ISO and HAL anesthesia compared to SEV anesthesia $(\mathrm{p}<0.001)$. Compared with $\mathrm{SV}, \mathrm{CV}$ prevented the increase in $\mathrm{PaCO}{ }_{2}$ $(\mathrm{p}<0.001)$ and no decrease in $\mathrm{pH}$ was observed $(\mathrm{p}<0.05)$. It is concluded that SEV anesthesia was appeared to have minimum complications on cardiopulmonary parameters in the healthy dogs which were premedicated with xylazine HCL and inducted with thiopental sodium. In the study, the use of CV was not associated with cardiovascular embarrassment during inhalation anesthesia and it was provide a more stable plane of anesthesia.
\end{abstract}

Key words: Controlled ventilation, dog, spontaneous ventilation, volatile anesthetics

\section{Köpeklerde sevofluran, izofluran ve halotan anestezilerinin spontan ve kontrollü ventilasyon sırasındaki kardiyopulmoner etkileri}

Özet: Bu çalışma ile köpeklerde spontan ventilasyon (SV) ve kontrollü ventilasyon (CV) sırasında sevofluran (SEV), izofluran (ISO) ve halothan (HAL) anestezilerinin kardiyopulmoner etkilerinin incelenmesi amaçlandı. Çalışma deneysel olarak planlandı ve çalışmada 60 sağlıklı melez köpek kullanıldı. Köpekler eşit olacak şekilde rastgele 6 anestezi grubuna ayrıldı: SEV/SV; SEV/CV; ISO/SV; ISO/CV; HAL/SV; HAL/CV. Xylazine HCL ile premedikasyonu takiben indüksiyon thiopental sodium ile yapıldı ve SEV, ISO ve HAL ile 90 dakika boyunca inhalasyon anestezisi oluşturuldu. Kardiyopulmoner parametreler [kalp frekansı (HR), solunum sayısı (RR), ortalama arteriyel kan basıncı (MAP), solunum sonu karbondioksit düzeyi $\left(\mathrm{ETCO}_{2}\right)$, oksijen saturasyonu $\left(\mathrm{SpO}_{2}\right)$, sentral venöz basınç (CVP), beden 1sısı, parsiyel arteriyel oksijen basıncı $\left(\mathrm{PaO}_{2}\right)$, parsiyel arteriyel karbondioksit basınc1 $\left(\mathrm{PaCO}_{2}\right)$ ve arteriyel $\mathrm{pH}$ ] ölçüldü. İlk ölçüm değeri, inhalasyon anestezikleri ile bilincin kaybolmasından bir dakika sonra, diğer ölçüm değerleri ise 15., 30., 45. 60. ve 90. dakikalarda kaydedildi. HR'de anestezik maddeler arasında SV ve CV sırasında belirgin bir farklılık kaydedilmedi. SV'de ISO ve HAL anestezileri ile RR anlamlı şekilde azaldı $(\mathrm{p}<0.001)$. MAP tüm gruplarda belirgin olarak azaldı fakat ventilasyon modları arasında belirgin bir farklılık gözlenmedi. SV ile karşılaştırıldığında, CV sırasında ETCO ${ }_{2}$ deki azalma belirgindi $(\mathrm{p}<0.001)$. SEV anestezisi ile SV sırasında CVP değerleri daha düşük seyretti $(p<0.001)$. Beden 1Sısı, ISO ve HAL anestezilerinde, SEV anestezisi ile karşılaştırıldığında anlamlı derecede düşüktü ( $p<0.001)$. CV, SV'ye göre $\mathrm{PaCO}_{2}$ artışını engelledi $(\mathrm{p}<0.001)$ ve $\mathrm{pH}$ 'da düşme gözlenmedi $(\mathrm{p}<0.05)$. Xylazine HCL ile premedikasyon ve thiopental sodium ile indüksiyonu yapılmış sağlıklı köpeklerde, SEV ile oluşturulan genel anestezi sırasında kardiyopulmoner parametreler üzerinde minimal komplikasyon oluştuğu sonucuna varıldı. Çalışmada, inhalasyon anestezisi sırasında CV'nun kullanılması ile daha stabil bir anestezi sağlandı.

Anahtar sözcükler: Kontrollü ventilasyon, köpek, spontan ventilasyon, volatil anestezik.

\footnotetext{
* This study was produced from doctorate thesis that is file number 2001/40 and supported by Management of Scientific Research Projects of the Uludag University.

Bu çalışma, Uludağ Üniversitesi Bilimsel Araştırma Projeleri Müdürlüğü tarafindan 2001\40 numaralı proje ile desteklenen doktora tezinden üretilmiştir.
} 


\section{Introduction}

Spontaneous ventilation (SV) is widely used during clinical anesthesia in dogs (17). All the inhalation anesthetic agents in current use produce a dosedependent respiratory depression in SV and decrease the response to carbon dioxide. Besides, they cause dosedependent reductions in tidal volume $\left(\mathrm{V}_{\mathrm{T}}\right)(19,23,37)$. Maintenance of adequate respiratory function is a prime requirement for safe general anesthesia (17, 38). Respiratory depression during general anesthesia may result from the effect of the anesthetics or alteration of the ventilation-perfusion ratio (30), but controlled ventilation (CV) compensates for such respiratory depression. In the anesthetized animal CV permits the respiratory frequency, gas exchange and pulmonary compliance to stay at normal values (29).

Halothane (HAL), isoflurane (ISO) and sevoflurane (SEV), have been used in the clinical practice of veterinary medicine $(15,23,36)$. Inhalation anesthesia induces a dose-dependent cardiopulmonary depression in all animals (29). It is well established that halogenated anesthetics, such as HAL and ISO, can alter cardiac rate and rhythm (24). ISO has been demonstrated to have less myocardial depressant properties (18). In experimental studies there are quite a lot of differences in cardiopulmonary parameters and between SEV, ISO and $\operatorname{HAL}(3,18,27)$. But clinically those differences are not always clear $(26,33)$. Mutoh and others (1997) reported the cardiopulmonary effects of SEV, in comparison to HAL, enflurane, and ISO in adult unpremedicated dogs using mask induction. In most experimental studies on volatile anesthetics in dogs the anesthetic protocol is reduced to the strict minimum to eliminate potential influences of other anesthetic drugs. Therefore, premedication and induction with intravenous anesthetic agents are excluded. Instead, anesthesia is induced and maintained solely by the volatile anesthetic agents (22). However, inhalant agents are not commonly agents used for induction of anesthesia in veterinary practice (25). In the present study the anesthetic protocol included a standard premedication, since preanaesthetics drugs are of major importance under clinical circumstances. Premedication decreases stress before induction of anesthesia, facilitates manipulations and contributes to a smooth induction and recovery from anesthesia $(15,36)$. Induction of anesthesia is mainly achieved by intravenous anesthetics because of their rapid onset of action and ease of administration (25).

To simulate clinical anesthesia, the dogs in this study were premedicated with xylazine $\mathrm{HCl}$ and induction was done with thiopental sodium. Premedication and induction certainly influence the cardiopulmonary and recovery parameters. Xylazine $\mathrm{HCl}$ can cause changes in the arterial partial pressure of oxygen $\left(\mathrm{PaO}_{2}\right)$, arterial partial pressure of carbon dioxide $\left(\mathrm{PaCO}_{2}\right)$ or arterial $\mathrm{pH}, \mathrm{HR}$ and blood pressure (14). Thiopental sodium may cause hypotension, bradycardia followed by reflex tachycardia, hypertension and arrhythmias in the cardiovascular system $(15,20,21,36)$.

In this study, dogs were anesthetized with xylazine $\mathrm{HCl}$ and thiopental sodium and maintained with SEV, ISO or HAL. The purpose was twofold; 1- determines the cardiopulmonary effects of the three inhalant agents; 2- compare the effects of SV and $\mathrm{CV}$ during anesthetic maintenance with the three inhalant agents'.

\section{Materials and Methods}

Animals: The study was approved by the Ethical committee of the Faculty of Veterinary Medicine, Uludag University (file number: 2001/40); no animals were euthanatized as a result of this study. Sixty healthy cross breed dogs of either sex, weighing from 11 to $28 \mathrm{~kg}$ (mean $17.1 \pm 4.8 \mathrm{~kg}$ ) and between 1 to 4 years of age were used for the study. Health status was evaluated by using standard physical examinations methods, complete blood counts and electrocardiograms. They were given commercial dog food and water ad libitum. No specific medication altering anesthetic or analgesic requirements was administered before the experiments.

Protocol: Dogs were randomly allocated to six groups ( $n=10$ in every group): SEV/SV; SEV/CV; $\mathrm{ISO} / \mathrm{SV} ; \mathrm{ISO} / \mathrm{CV} ; \mathrm{HAL} / \mathrm{SV} ; \mathrm{HAL} / \mathrm{CV}$. Food but not water was withheld for 12 hours before each experiment. Anesthesia was carried out in a room in which the temperature was kept between 21 to $24{ }^{\circ} \mathrm{C}$.

Premedication and induction of anesthesia: The dogs were premedicated with xylazine $\mathrm{HCl}(1 \mathrm{mg} / \mathrm{kg}$; Alfazyn ${ }^{\circledR} \%$ 2, Alfasan / Ege Vet, Turkey) intramuscularly (IM) 30 minutes before induction of anesthesia (35). All dogs were placed in right lateral recumbency and an intravenous (IV) catheter was placed in the cephalic vein. Induction of anesthesia was performed by using $2.5 \%$ thiopental sodium $(10 \mathrm{mg} / \mathrm{kg}$; Penthotal Sodium ${ }^{\circledR}$, Abbott, UK) (34) intravenously over 15-20 seconds. After the loss of the swallowing reflex, the dogs were orally intubated [using a cuffed endotracheal tube (Bicakcilar, Turkey, 8.5 or $9 \mathrm{~mm}$ ID)]. Ringer's solution $(10 \mathrm{ml} / \mathrm{kg} / \mathrm{h}$; Baxter Corporation, Istanbul, Turkey) which was warmed to $37^{\circ} \mathrm{C}$ was infused during the anesthesia (2).

Maintenance of anesthesia: A semi-closed circle rebreathing anesthesia system (AMS 200; AMS, Ankara, Turkey) was used throughout the study. Anesthesia maintained with SEV (Sevorane ${ }^{\circledR}$; Abbott, Chicago, USA), ISO (Forane ${ }^{\circledR}$; Abbott, UK), or HAL (Fluothane ${ }^{\circledR ;}$; Zeneca, Istanbul, Turkey) in oxygen ( $100 \%$ 
oxygen at a flow rate of $20 \mathrm{ml} / \mathrm{kg} / \mathrm{min}$ ) at concentrations of 3, 2 and $1.5 \%$, respectively. SEV was administered using a flow compensated vaporizer (Blease, Genuine Part, England), ISO was administered using an Isoflurane A-3 vaporizer (Kimura Medical CO., Tokyo, Japan) and HAL was administered using a Fluotec-3 vaporizer (Cyprae Keighley, England). The dials of the vaporizers were progressively reduced to the percentage required to maintain a plane of anesthesia sufficient to avoid a clinical response to a tail clamp, movements, and changes in HR, RR and blood pressure while being close to the lower of the published minimum alveolar concentrations (MACs). If no response to the tail clamp was noted, the dial was reduced from $3 \%$ to $2.5 \%$ for SEV , from $2 \%$ to $1.5 \%$ for ISO and from $1.5 \%$ to $1 \%$ for HAL. The entire experimental protocol was finished after 90 minutes.

Measurements and monitoring: The dogs were ventilated using intermittent positive pressure ventilation (IPPV) in controlled ventilation groups. CV (tidal volume, $15 \mathrm{ml} / \mathrm{kg}$; respiration rate, $12-14 / \mathrm{min}$ ) was started immediately after intubation. $\mathrm{RR}$ and tidal volume were adjusted to maintain an $\mathrm{ETCO}_{2}$ concentration between 35 and $45 \mathrm{~mm} \mathrm{Hg}$ (measured by continuous capnography; Normocap 200; Datex-Ohmeda Helsinki, Finland).

During anesthesia, $\mathrm{ETCO}_{2}$ and $\mathrm{RR}$ were monitored continuously with capnograph. Oxygen saturation $\left(\mathrm{SpO}_{2}\right.$; measured by continuous pulse oxymetry; Vet/OXTM 4403; SDI Fort Collins, CO, USA) was read and pulse rate was obtained with pulse oximeter with the probe placed on the tongue. Body temperature was obtained with an esophageal pulse oximeter probe (with auscultation and temperature monitoring capability). A catheter was placed in the femoral artery to measure the arterial blood pressure and collect arterial blood samples. Mean arterial blood pressure (MAP) was measured through the arterial catheter by using an aneroid manometer (Riester, minimus III, Germany). Arterial blood samples were taken anaerobically into heparinized syringes. Arterial partial pressure of oxygen $\left(\mathrm{PaO}_{2}\right)$, arterial partial pressure of carbon dioxide $\left(\mathrm{PaCO}_{2}\right)$, and arterial $\mathrm{pH}$ were measured with a blood gas analyzer (Chiron Diagnostic, Rapid $\mathrm{lab}^{\mathrm{TM}} 248$, UK) at $37^{\circ} \mathrm{C}$ and corrected for each dog's temperature. A jugular vein catheter was placed to measure central venous pressure (CVP) into the anterior vena cava via the jugular vein and connected to a CVP manometer (REF 110, Bicakcilar, Turkey).

The first measurement was one min after the loss of consciousness with SEV, ISO, or HAL and the others were done at $15 \mathrm{th}, 30 \mathrm{th}, 45 \mathrm{th}, 60 \mathrm{th}$ and 90 th minutes. After anesthesia, all dogs were extubated and observed in the post-anesthesia care unit for the next $2 \mathrm{~h}$.
Statistical analyses: Statistical analysis was performed using SPSS 11.0 version for Windows (SPSS Inc., Chicago, IL, USA). All data were expressed as mean \pm standard deviation (SD). After the assessment of normality assumption, repeated measures ANOVA with between-subjects factors (with independent measures on drug groups and ventilation groups, repeated measures on time periods) were performed with Greenhouse-Geisser adjustment for $\mathrm{HR}$, MAP, ETCO ${ }_{2}$, temperature, $\mathrm{PaO}_{2}$, $\mathrm{PaCO}_{2}$ and $\mathrm{pH}$. Nonparametric tests were performed for $\mathrm{RR}, \mathrm{SpO}_{2}$ and CVP. Wilcoxon-Signed Ranks test was used for the comparison of the distributions amongst the drug and ventilation groups. Kruskal Wallis chi-square test and Mann-Whitney U-test were used for percent changes over the time period according to baseline results to compare the groups. A p value of less than 0.05 was regarded as statistically significant difference.

\section{Results}

Descriptive statistics of the measurements of the cardiopulmonary function of the dogs in each drug group with SV or CV recorded at $0,15,30,45,60$ and $90 \mathrm{~min}$ are presented in Table 1.

There was no significant difference in HR between the ventilation groups or anesthetic agents $(p>0.05)$. HR did not change during the different anesthetic times when compared to first measurement values ( $p>0.05$ ).

ISO and HAL caused a significant decrease in RR when compared with first measurement values in SV groups $(\mathrm{p}<0.001)$.

Time had significant influences on the MAP in all protocols $(\mathrm{p}<0.001)$. MAP decreased significantly in all groups. There was not any significant difference between the ventilation modes in MAP ( $p>0.05)$.

$\mathrm{ETCO}_{2}$ increased significantly in all groups during the 15, 30, 45, 60 and 90 minutes when it was compared to the first measurement values $(\mathrm{p}<0.001)$. There was a significant decrease in $\mathrm{ETCO}_{2}$ during $\mathrm{CV}$ compared to SV $(p<0.001)$. There was no significant difference in $\mathrm{ETCO}_{2}$ between the anesthetic agents $(\mathrm{p}>0.05)$.

There were not any significant difference in $\mathrm{SpO}_{2}$ during the anesthesia period between the different anesthetic agents and the different ventilation groups $(\mathrm{p}>0.05)$.

The CVP values during anesthesia with SEV in SV were lower than those of other anesthetics $(p<0.001)$. The CVP decreased significantly during the 45, 60 and 90 minutes $(p=0.001, p=0.003, p=0.022$ respectively) when compared to the first measurement values in ISO anesthesia during CV. However, the CVP decreased significantly during the 45, 60 and 90 minutes when compared to the first measurement values in both ISO and HAL anesthesia in SV ( $p=0.001, p=0.005, p=0.012$ respectively). 


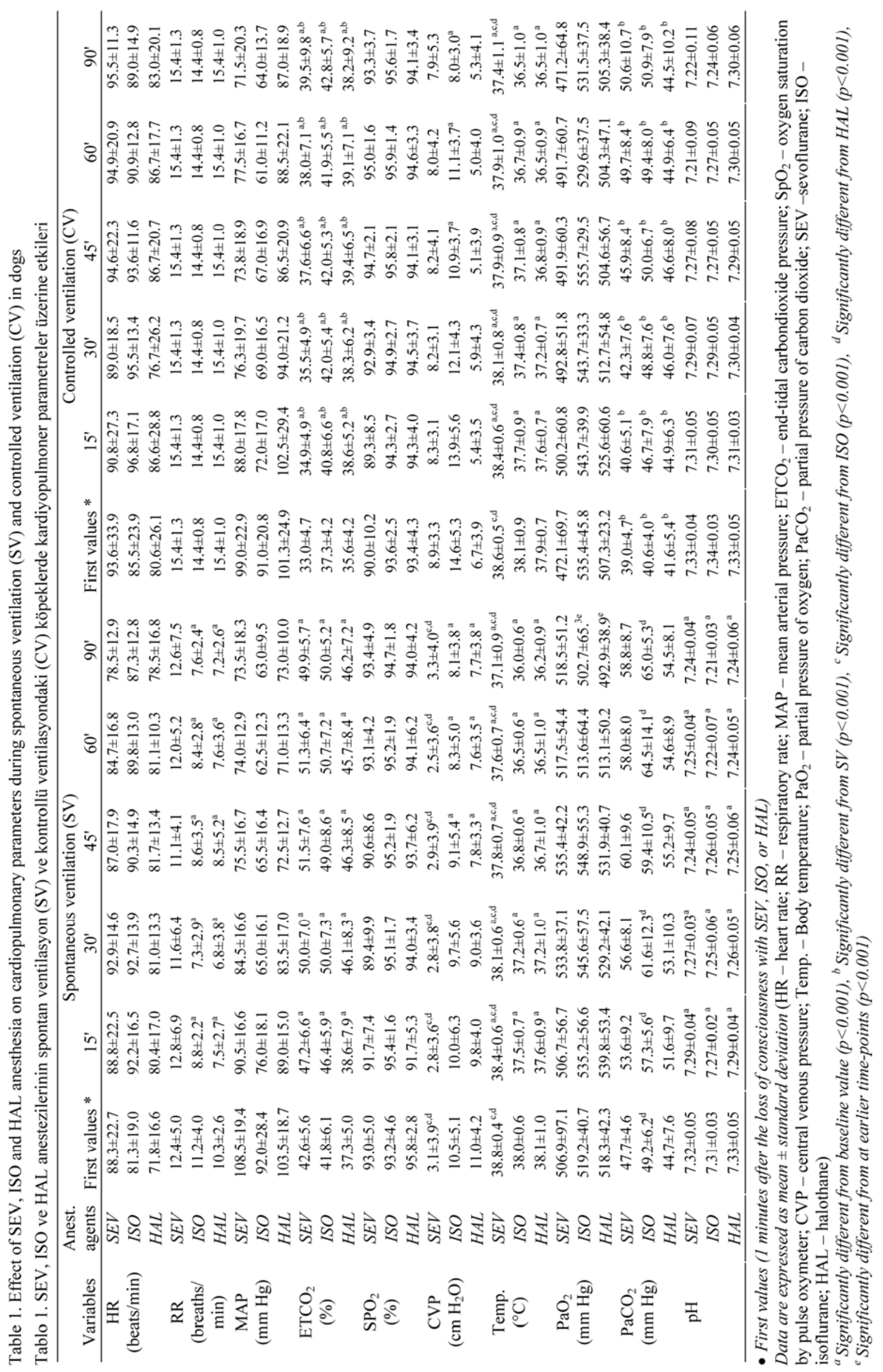


Body temperature decreased significantly in all groups during the 15, 30, 45, 60 and 90 minutes when compared to the first measurement values $(p<0.001)$. Body temperature was significantly higher during SEV anesthesia than it was during ISO and HAL anesthesia $(p<0.001)$. There was no significant difference in body temperature between the ventilation groups $(\mathrm{p}>0.05)$.

There was not any significant difference in $\mathrm{PaO}_{2}$ between the ventilation modes and anesthetic agents $(p>0.05)$. However, time had significant influences on the $\mathrm{PaO}_{2} \cdot \mathrm{PaO}_{2}$ was significantly lower at 90 min than it was at earlier time-points during ISO and HAL anesthesia in SV $(\mathrm{p}<0.001)$.

All anesthetics induced significant increases in $\mathrm{PaCO}_{2}$ and significant decreases in $\mathrm{pH}$ during $\mathrm{SV}$ groups at 15, 30, 45, 60 and 90 minutes when compared to the first measurement values $(\mathrm{p}<0.001) . \quad \mathrm{PaCO}_{2}$ was significantly higher at ISO anesthesia compared to HAL anesthesia during $\mathrm{SV}$ at all time $(\mathrm{p}=0.043)$. CV protocol prevented the increase in $\mathrm{PaCO}_{2}$ seen with $\mathrm{SV}$ groups $(\mathrm{p}<0.001)$. No fall in $\mathrm{pH}$ was observed in $\mathrm{CV}$ groups compared to SV $(p=0.038)$. There was no significant difference in $\mathrm{pH}$ between the anesthetic agents $(\mathrm{p}>0.05)$.

In all parameters, no interaction effects were observed among the drug groups and ventilation groups and time period $(\mathrm{p}>0.05)$.

\section{Discussion and Conclusion}

The medications which were mentioned in this study for premedication and induction were used in every $\mathrm{dog}$ in the same doses for $\mathrm{kg}$ of body weight. The premedication and induction values were not evaluated statistically because it was thought that these medications would cause similar cardiovascular effects in all dogs.

All three inhalants have important effects on the cardiovascular system $(32,37)$. In unpremedicated dogs SEV induces a rise in HR from 1.2 MAC on $(3,23)$. Activation of the baroreceptor-reflex, induced by a decreased MAP, was reported to be mainly responsible for this rise in HR. ISO also gives an increased HR in unpremedicated dogs (18). In contrast, HAL has little influence on HR in dogs, a slight increase was observed in dogs (27). These findings might be an indication for a less depressant effect to baroreceptor-reflex function with SEV and ISO compared to HAL $(1,3,27)$. In the present study, HR was lower during HAL anesthesia than it is during ISO and SEV anesthesia at both ventilation modes but this difference was not statistically significant. However, there was not any significant difference in HR between ISO and SEV anesthesia ( $p>0.05)$.

$\mathrm{CV}$ is frequently necessary during general anesthesia but the use of ventilatory assistance may cause hemodynamic embarrassment. The cardiovascular depression observed during $\mathrm{CV}$ is caused by multifactorial effects (28). CV reduces venous return and lowers cardiac output $(\mathrm{CO})(19,31)$. Thus HR will increase to compensate for decreasing $\mathrm{CO}$ in $\mathrm{CV}$ groups $(3,7,29)$. But there was not any significant difference in HR between SV and CV in the present study.

All volatile anesthetic agents cause a dose-related respiratory depression in dogs (23). HAL is the least respiratory depressant of the three inhalant agents in the $\operatorname{dog}(22,23,32)$. ISO and SEV showed a similar degree of respiratory depression, though only SEV was significantly worse than HAL (23). In the present study, a significant decrease in RR was observed during ISO and HAL in SV dogs. No fall in RR was observed during SEV anesthesia in SV dogs. This is in contrast to the literature, where SEV is a more potent ventilatory depressant than HAL (9), and the characteristics of the ventilatory depression associated with SEV are similar to those of ISO (1, 6). Mutoh and others (1997) reported that ISO in dogs induced a depression in RR. This is in agreement with the findings in our study results.

Arterial blood pressure is a product of systemic vascular resistance and CO (5). Whilst by no means the best single indicator, MAP does illuminate elements of the health of the cardiovascular system under anesthesia. MAP values were derived by using the standard of intraarterial catheterization. MAP values have been shown to be generally lower with SEV and ISO in comparison to HAL anesthesia $(3,7,22,23)$. In present study, a more significant decrease was recorded in the values of MAP during ISO anesthesia in both ventilation groups. It was thought that this great decrease in MAP during ISO anesthesia because HR in compensation was probably higher than during SEV and HAL anesthesia (18). MAP values which were recorded during SEV and ISO anesthesia in CV group were lower when they were compared to HAL anesthesia as it was reported in previous studies. However, MAP values which were recorded during SEV and HAL anesthesia in SV group were close to each other. But, statistically significant differences were not demonstrated between the ventilation modes in MAP.

$\mathrm{ETCO}_{2}$ was considered to be the most useful single indicator of respiratory function available within the limitations of the clinical environment, as commonly used in previous studies. SEV and ISO have previously been shown to depress respiratory function more than $\mathrm{HAL}$, in terms of ETCO2 readings $(22,23,32)$. The values of $\mathrm{ETCO}_{2}$ in the present study, which is also presented compatible with literature, tended to be slightly higher for SEV and ISO anesthetics when they were compared to the ones for HAL anesthesia in SV. But, these increases which were recorded in $\mathrm{ETCO}_{2}$ readings remained in the acceptable range and there was not any statistically significant difference in $\mathrm{ETCO}_{2}$ between the 
anesthetic agents. $\mathrm{ETCO}_{2}$ values were recorded lower compared with SV as they should have been because hypoventilation was prevented with $\mathrm{CV}$.

Significant correlation between $\mathrm{ETCO}_{2}$ and $\mathrm{PaCO}_{2}$ has been recorded in dogs. $\mathrm{ETCO}_{2}$ values exceeding 50 mmHg represent increased $\mathrm{PaCO}_{2}$ and significant hypoventilation (10). In the majority of the anesthetized animals breathing spontaneously, the $\mathrm{PaCO}_{2}$ rises to values higher than $45 \mathrm{mmHg}$. Increased $\mathrm{PaCO}_{2}$ (hypercapnia) is a direct consequence of hypoventilation and commonly occurs during anesthesia. $\mathrm{PaCO}_{2}$ values exceeding $60 \mathrm{mmHg}$ are indicative of significant respiratory depression. It is reported that hypercapnia in dogs particularly occurs during HAL anesthesia (9). The results of our study support this data. In this study values for $\mathrm{PaCO}_{2}$ in the dogs in SV during ISO anesthesia were more significant and they increased during SEV and HAL anesthesia when they were compared with the values at the beginning and a significant decrease was recorded in the dogs in SV during RR, ISO and HAL anesthesia.

As expected, $\mathrm{CV}$ maintained $\mathrm{PaCO}_{2}$ within acceptable limits. With $\mathrm{CV}$, the decrease in cardiac output appears to be due to a decrease in venous return as a result of increased intrathoracic pressure, and perhaps decreased vagus nerve activity as a result of a decrease in $\mathrm{PaCO}_{2}(13,19,29)$. The authors reported that in a group of $\mathrm{CV}$ dogs, the $\mathrm{ETCO}_{2}$ was on average $5 \mathrm{mmHg}$ less than $\mathrm{PaCO}_{2}$ (13). This is in agreement with the findings in our study results.

$\mathrm{PaO}_{2}$ and $\mathrm{SpO}_{2}$ during anesthesia were higher in all inhalation groups due to a high inspired oxygen fraction. For the same reason $\mathrm{PaO}_{2}$ and $\mathrm{SpO}_{2}$ values were normal during anesthesia and not different between the anesthetic groups despite a higher $\mathrm{PaCO}_{2}$ and lower RR in SV.

In veterinary patients, the CVP is commonly measured in cranial vena cava (via jugular vein) (16). No adverse reactions or complications (thrombophlebitis, septicemia, air embolism, and vascular endothelial damage) were encountered after performance of jugular catheterizations in this study. The CVP values during anesthesia with SEV in SV were lower than other anesthetics. It can be explained that the measurements is usually taken at the end of spontaneous inspiration because CVP decreases during spontaneous inspiration (12). The CVP values during anesthesia with ISO in CV were higher than other anesthetics. $\mathrm{CV}$ might increase CVP. However, the CVP values have been evaluated within the physiological reference range in all anesthetic groups (11).

Time had influences on the body temperature. Body temperature significantly decreased during HAL and ISO anesthesia compared with SEV anesthesia. This situation may be explained with the different individual peripheral vasodilator properties of inhalation anesthetics and as effects depressed on heat regulation $(3,8,35,36)$.

This study showed that SEV and ISO produced similar cardiopulmonary effects in the healthy dogs which were premedicated with xylazine $\mathrm{HCL}$ and inducted with thiopental sodium.

However, the present findings indicate that respiratory effects of SEV were less than those of ISO and HAL in the SV dogs. SV is mostly used during clinical anesthesia in dogs. But this mode of breathing is often accompanied with hypoventilation. SEV can be used safely in dogs undergoing SV. In study, the influences of $\mathrm{CV}$ were compared with the $\mathrm{SV}$ in dogs. $\mathrm{CV}$ had beneficial effects on cardiopulmonary parameters in comparison to SV during SEV, ISO or HAL anesthesia. $\mathrm{CV}$ overcomes the occurring hypoventilation (4). In the present study, the use of CV in dogs was not associated with cardiovascular embarrassment during inhalation anesthesia and it was provide a more stable plane of anesthesia.

\section{Acknowledgement}

Linguistic aspects of this manuscript were revised by Hasan Sahin of Uludag University, School of Foreign Languages, Bursa, Turkey.

\section{References}

1. Apaydın N, Koç B (2005): Köpeklerde Isoflurane ve Sevoflurane Anestezisinin Hemodinamik ve Biyokimyasal Parametrelere Olan Etkilerinin Karsılastırılmasl, Vet Cer Derg, 11, 31-35.

2. Bednarski RM (1996): Anesthesia and immobilization of specific species. Dogs and cats. 593. In: JC Thurmon, WJ Tranquilli and GJ Benson (Eds) Lumb and Jones' Veterinary Anesthesia, $3^{\text {rd }}$ ed. Williams \& Wilkins, Baltimore.

3. Bernard JM, Wouters PF, Doursout MF, Florence B, Chelly JE, Merin RG (1990): Effects of sevoflurane and isoflurane on cardiac and coronary dynamics in chronically instrumented dogs. Anesthesiology, 72, 659-662.

4. Cullen DJ, Eger E III (1974): Cardiovascular effects of carbon dioxide in man. Anesthesiology, 41, 345.

5. Ebert TJ, Harkin CP, Muzi M (1995): Cardiovascular responses to sevoflurane: a review. Anesth Analg, 81, 11-22.

6. Fourcade HE, Stevens WC, Larson CP, Cromwell TH, Bahlman SH, Hickey RF, Halsey MJ, Eger EIII (1971): The ventilatory effects of forane, a new inhaled anesthetic. Anesthesiology, 35, 26-31.

7. Frink EJ, Morgan SE, Coetzee A, Conzen P, Brown BJ (1992): The effects of sevoflurane, halothane, enflurane and isoflurane on hepatic blood flow and oxygenation in chronically instrumented greyhound dogs. Anesthesiology, 76, 85- 90.

8. Gorgul OS (1998): Anestezi. 532-536. In: Imren (Ed), Kedi ve köpek hastalıkları, 1.baskı. Medisan yayın serisi no: 32, Ankara 
9. Green WB (1995): The ventilatory effects of sevoflurane. Anesth Analg, 81, 23-26.

10. Hall LW, Clarke KW, Trim CM (2001): Anaesthesia of the dog. 385-439. In: LW Hall, KW Clarke, CM Trim (Eds), Veterinary Anaesthesia, $10^{\text {th }}$ ed. W.B. Saunders, London.

11. Haskins SC (1999): Perioperative monitoring. 123-146. In: RR Paddleford (Ed), Manual of Small Animal Anesthesia, 2nd ed. W. B. Saunders Co, Philadelphia.

12. Kaplan PM (1992): Monitoring. 21-37. In: RJ Murtaugh, PM Kaplan (Eds), Veterinary Emergency and Critical Care Medicine. Mosby Year Book, St. Louis.

13. King LG, Hendricks JC (1994): Use of positive-pressure ventilation in dogs and cats: 41 cases (1990-1992). J Am Vet Med Assoc, 204, 1045-1052.

14. Klide AM, Calderwood HW, Soma LR (1975): Cardiopulmonary effects of xylazine in dogs. Am J Vet Res, 36, 931-935.

15. Koç B, Sarıtaş KZ (2004): Genel anestezi, 85-104. In: Veteriner Anesteziyoloji ve Reanimasyon. Medipres Matbaacılık, Malatya.

16. Machon RG, Raffe MR, Robinson EP (1995): Central venous pressure measurements in the caudal vena cava of sedated cat. J Vet Emerg Crit Care, 5, 121-129.

17. Mc Donell W (1996): Respiratory system. 115-147. In: JC Thurmon, WJ Tranquilli, GJ Benson (eds), Lumb and Jones' Veterinary Anesthesia, $3^{\text {rd }}$ ed. Williams \& Wilkins, Baltimore.

18. Merin RG, Bernard JM, Doursout MF, Cohen M, Chelly JE (1991): Comparison of the effects of isoflurane and desflurane on cardiovascular dynamics and regional blood flow in the chronically instrumented dog. Anesthesiology, 74, 568-574.

19. Muir WW, Hubbell JAE, Skarda R (1995): Handbook of Veterinary Anesthesia, 209-219. In: WW Muir, JAE Hubbell (Eds) $2^{\text {nd }}$ ed. Mosby-Year Book, St.Louis.

20. Muir WW (1998a): Anesthesia for dogs and cats with cardiovascular disease - Part I. Compend Cont Educ Pract Vet, 20, 78-87.

21. Muir WW (1998b): Anesthesia for dogs and cats with cardiovascular disease - Part II. Compend Cont Educ Pract Vet, 20, 473-484.

22. Mutoh T, Nishimura R, Kim HY, Matsunaga S, Kadosawa T, Mochizuki M, Sasaki N (1995): Rapid inhalation induction of anesthesia by halothane, enflurane, isoflurane and sevoflurane and their cardiopulmonary effects in dogs. J Vet Med Sci, 57, 1007-1013.

23. Mutoh T, Nishimura R, Kim HY, Matsunaga S, Sasaki N (1997): Cardiopulmomary effects of sevoflurane, compared with halothane, enflurane and isoflurane, in dogs. Am J Vet Res, 58, 885-890.

24. Nakaigawa Y, Akazawa S, Shimizu R, Ishii R, Yamato $\mathbf{R}$ (1995): Comparison of the effects of halothane, isoflurane, and sevoflurane on atrioventricular conduction times in pentobarbital-anesthetized dogs. Anesth Analg, 81, 249-253.

25. Nicholson A, Watson ADJ (2001): Survey of small animal anaesthesia. Aust Vet J, 79, 613-619.
26. Oliva VNLS, Aguiar AJA, Eugênio FR, Andrade AL, Guimaraes CRCB, Perri SHV (2002): Sevoflurane or halothane anaesthesia after propofol or thiopentone induction for orthopedic surgery in dogs. Vet Anaesth Analg, 1, 75-79.

27. Pagel PS, Kampine JP, Schmeling WT (1991): Comparison of the systemic and coronary hemodynamic actions of desflurane, isoflurane, halothane, and enflurane in the chronically instrumented dog. Anesthesiology, 74, 539-551.

28. Perel A, Pizov R (1992): Cardiovascular effects of mechanical ventilation. 51-65. In: A Perel, MC Stock (Eds), Mechanical Ventilatory Support. Williams \& Wilkins, Baltimore.

29. Polish I, Gasthuys F, Laevens H, Van Ham L, De Rick A (2001): The influence of ventilation mode (spontaneous ventilation, IPPV and PEEP) on cardiopulmonary parameters in sevoflurane anaesthetized dogs, J Am Vet Med Assoc, 48, 619-630.

30. Short CE (1987): Inhalant anesthetics. 70 -90. In: Principles \& Practice of Veterinary Anesthesia. Williams \& Wilkins, Baltimore.

31. Steffey EP, Howland DJR (1977): Isoflurane potency in the dog and cat. Am J Vet Res, 38, 1833-1836.

32. Steffey EP (1996): Inhalation anesthetics. 297-329. In: JC Thurmon, WJ Tranquilli, GJ Benson (Eds), Lumb and Jones' Veterinary Anesthesia, $3^{\text {rd }}$ ed. Williams \& Wilkins, Baltimore.

33. Tacke S, Xiong, Schimke E (2000): Sevoflurane anaesthesia in dogs after premedication with L-methadone, diazepam and propofol in comparison to halothane and isoflurane, in Proceedings. 7th World Congress of Veterinary Anaesthesia Berne Sept. 20-23:79.

34. Thurmon JC, Tranquilli WJ, Benson GJ (1996b): Injectable anesthetics. 210-225. In: JC Thurmon, WJ Tranquilli, GJ Benson (Eds) Lumb and Jones' Veterinary Anesthesia, ${ }^{\text {rd }}$ ed. Williams \& Wilkins, Baltimore.

35. Topal A (2001): Anestezik ilaçlar ve anestezi teknikleri. 36-60. In: Veteriner Anesteziyoloji ve Reanimasyon Ders Notu, Uludag Üniversitesi Veteriner Fakültesi yayınları No:1, Bursa.

36. Topal A (2005) İnhalasyon anesteziklerinin özellikleri ve inhalasyon anestezikleri, 131-148. In: Veteriner Anestezi, Nobel \& Güneş Tıp Kitapevi, Bursa.

37. Wallin RF, Regan BM, Napoli MD, Stern IJ (1975): Sevoflurane: A new inhalational anesthetic agent, Anesth Analg, 54, 758-766.

38. Wright B, Hellyer WP (1996): Pulse oximetry and capnography, Respiratory monitoring during anesthesia, Compend Cont Educ Pract Vet, 18, 1083-1097.

Geliş tarihi: 06.03.2008 / Kabul tarihi: 26.01.2009
Address for correspondence
Yrd. Doç. Dr. Göksen Çeçen
Department of Surgery, Faculty of Veterinary Medicine,
University of Uludag
Görükle, Bursa - Türkiye
e-mail : goksenc@uludag.edu.tr 